\title{
Temporal and vertical variations of aerosol physical and chemical properties over West Africa: AMMA aircraft campaign in summer 2006
}

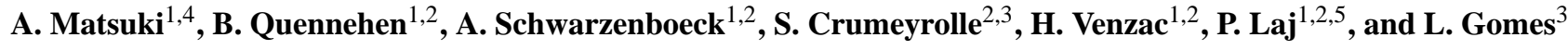 \\ ${ }^{1}$ Université Blaise Pascal, Clermont Université, Clermont-Ferrand, France \\ ${ }^{2}$ Laboratoire de Météorologie Physique, CNRS, Clermont-Ferrand, France \\ ${ }^{3}$ Centre National de Recherches Météorologiques, Météo-France, Toulouse, France \\ ${ }^{4}$ Frontier Science Organization, Kanazawa University, Japan \\ ${ }^{5}$ Laboratoire de Glaciologie et Géophysique de l'Environnement, CNRS, Grenoble, France
}

Received: 24 December 2009 - Published in Atmos. Chem. Phys. Discuss.: 15 February 2010

Revised: 20 August 2010 - Accepted: 31 August 2010 - Published: 7 September 2010

\begin{abstract}
While the Sahelian belt in West Africa stretches in the border between the global hot-spots of mineral dust and biomass burning aerosols, the presence of West African Monsoon is expected to create significant vertical and temporal variations in the regional aerosol properties through transport and mixing of particles from various sources (mineral dust, biomass burning, sulfates, sea salt). In order to improve our understanding of the evolution of the aerosolcloud system over such region across the onset of the summer monsoon, the French ATR-42 research aircraft was deployed in Niamey, Niger $\left(13^{\circ} 30^{\prime} \mathrm{N}, 02^{\circ} 05^{\prime} \mathrm{E}\right)$ in summer 2006, during the three special observation periods (SOPs) of the African Monsoon Multidisciplinary Analysis (AMMA) project. These three SOPs covered both dry and wet periods before and after the onset of the Western African Monsoon.

State of the art physico-chemical aerosol measurements on the ATR-42 showed a notable seasonal transition in averaged number size distributions where (i) the Aitken mode is dominating over the accumulation mode during the dry season preceding the monsoon arrival and (ii) the accumulation mode increasingly gained importance after the onset of the West African monsoon and even dominated the Aitken mode after the monsoon had fully developed. The parameters for the mean log-normal distributions observed in respective layers characterized by the different wind regimes (monsoon layer, SAL, free troposphere) are presented, together with
\end{abstract}

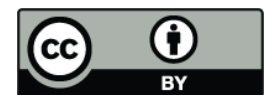

Correspondence to: A. Matsuki (matsuki@staff.kanazawa-u.ac.jp) the major particle compositions found in the accumulation mode particles. Thereby, results of this study should facilitate radiative transfer calculations, validation of satellite remote sensors, and detailed transport modeling by partners within and outside the AMMA community.

Extended analysis of the chemical composition of single aerosol particles by a transmission electron microscope (TEM) coupled to an energy dispersive X-ray spectrometer (EDX) revealed dominance of mineral dust (aluminosilicate) even in the submicron particle size range during the dry period, gradually replaced by prevailing biomass burning and sulfate particles, after the onset of the monsoon period. The spatial and temporal evolution from SOP1 to SOP2a1 and SOP2a2 of the particle physical and chemical properties and associated aerosol hygroscopic properties are remarkably consistent.

\section{Introduction}

Aerosols are known to have significant impact on the regional and global climate via interaction with the solar and terrestrial radiation, thereby modifying the planetary albedo and the outgoing longwave radiation (Intergovernmental Panel on Climate Change, 2007). Aerosols can be either natural or man-made, that are formed directly from the source as primary particles (mineral dust, sea salt, soot, biomass burning smoke, biogenic debris), or as secondary particles (sulfates, nitrates, organic) following condensation of precursor gases. The African continent represents by far

Published by Copernicus Publications on behalf of the European Geosciences Union. 
the largest global sources of both mineral dust and biomass burning aerosols (Woodward 2001; Bond et al., 2004).

Despite the recent advances in radiometry from satellite (Christopher et al., 2008; Winker et al., 2007), the accurate prediction of the aerosol radiative impact at the regional scale is still hampered by the difficulties in precisely describing the vertical extension of particle transport, modification, and interaction with cloud microphysics. This is particularly the case over regions such as West Africa, where the presence of the monsoon is expected to cause strong seasonal and spatial variation in the aerosol physico-chemical properties (size distribution, shape, composition, hygroscopicity) through their transport, mixing, aging, sedimentation, and cloud processing.

The significance and paucity of measurements over the African continent have led to the coordination of several large-scale field campaigns such as Saharan Dust Experiment (SHADE) focusing on mineral dust outbreaks in West Africa (Tanré et al., 2003), the Saharan Mineral Dust Experiment (SAMUM-1) project in Northwestern Africa (Heintzenberg, 2009), and the Southern African Regional Science Initiative (SAFARI, 2000) in the southern Africa region that focus on biomass burning particles (Swap et al., 2003). The main scope of these past experiments has been focusing on the characterization of either the dust or biomass burning particles.

The mixing between these two aerosol types (dust, biomass burning) and its impact on the radiative budget has been particularly addressed in campaigns such as the followup SAMUM-2 (Heintzenberg, 2009), the Dust and Biomass Experiment (DABEX) (Haywood et al., 2008), and Dust Outflow and Deposition to the Ocean (DODO-1) (McConnell et al., 2008). These intensive measurement campaigns, deploying amongst other research aircrafts over West Africa, have demonstrated the extent of mixing and westward transport of both aerosol types across the continent and over the Atlantic (Capes et al., 2008; Chou et al., 2008; Formenti et al., 2008). These measurements were held during the months of January and February, representing the dry season. DABEX and DODO-1 were organized jointly with the African Monsoon Multidisciplinary Analysis (AMMA) winter Special Observation Period (SOP0).

The AMMA campaign is a major international project to improve our knowledge and understanding of the West African Monsoon (WAM) and its daily to inter-annual variabilities and the associated impacts on issues such as health, water resources, and food security. The atmospheric dust and biomass-burning aerosols play a major role in radiative forcing and in cloud microphysics, and thus are an important part of the WAM system which requires further study. An overview of the AMMA project can be found elsewhere (Redelsperger et al., 2006; Lebel et al., 2009).

To be contrasted with the previous measurement campaigns, our objective was to conduct in-situ characterization of aerosols before and after the onset of the summer mon- soon. Therefore in 2006 the French research aircraft ATR-42 was deployed over Niamey during the three special observation periods SOP1, SOP2a1, and SOP2a2 of the AMMA project.

An overall scope of this paper is to give an overview of the seasonal and spatial evolution of the aerosol size distribution, chemical composition, mixing states, and hygroscopic nature of the atmospheric aerosols over West Africa across the onset of the characteristic summer monsoon. Although the frequent development and passage of Mesoscale Convective Systems (MCS) is the key feature of the monsoon season over the studied area, the multiple interactions of individual MCS and the regional aerosol properties are not within the scope of this study and discussed more in detail by Crumeyrolle et al. (2008).

\section{ATR-42 aircraft measurements}

In order to carry out an extended aerosol in-situ characterization of wide temporal and spatial coverage, the French ATR-42 research aircraft was deployed in Niamey, Niger $\left(13^{\circ} 30^{\prime} \mathrm{N}, 02^{\circ} 05^{\prime} \mathrm{E}\right)$ during the three special observation periods (SOPs) of the AMMA project. The aircraft joined the project during SOP1 (1-15 June 2006), SOP2a1 (1-13 July 2006), and SOP2a2 (2-19 August 2006). Each of the three SOPs represents "dry", "monsoon onset", and "high monsoon (Wet)" periods, respectively. The dates and durations of the flights are summarized in Fig. 1. SOP1 was completed before the monsoon onset when rainfall events were still scarce (Fig. 1). During the second observation period after 1 July, half of the flights were conducted following significant rainfall within the previous $24 \mathrm{~h}$ (Saïd et al., 2009).

The results presented here are based mainly on the vertical exploration flights conducted intensively in the low and mid troposphere $(0.1-5 \mathrm{~km}$ a.s.1.) over the Sahel region in the vicinity of Niamey. One representative flight track of the ATR-42 aircraft is shown in Fig. 2. The interesting flights for this study were composed of 4-7 stacked horizontal legs during descents mostly centered over Banizoumbou $\left(13^{\circ} 32^{\prime} \mathrm{N}, 2^{\circ} 40^{\prime} \mathrm{E}, 250 \mathrm{~m}\right.$ a.s.1.), $55 \mathrm{~km}$ east of Niamey where the projects' ground based observational supersite was located. In some flights during the fully developed monsoon period (i.e. SOP2a2), however, the flights were performed over the regions of the predicted passage of an approaching Mesoscale Convective System (MCS) or after the MCS had passed through.

The ATR-42 was equipped with a community aerosol inlet (CAI). The CAI is an isokinetic forward facing aerosol inlet designed for ATR-42 aircraft. Most recent calibration studies of the CAI inlet in the ECN chamber (Petten, Netherlands), proved that CAI collects particles smaller than $4 \mu \mathrm{m}(50 \%$ collection efficiency) (L. Gomes, personal communication, 2009). The air was introduced into the cabin through the CAI inlet and further divided into flows passing through the onboard instrumental devices. 


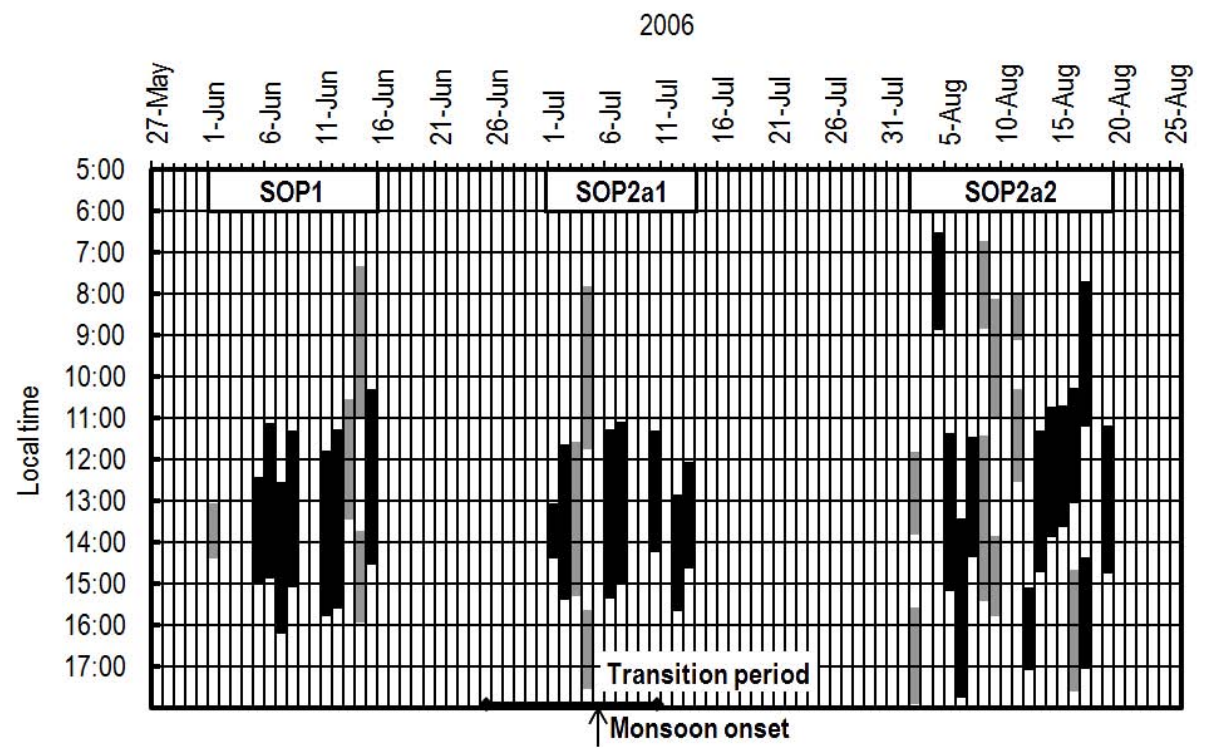

Fig. 1. Time scale of the AMMA Special Observation Periods (SOP) and flight hours of the intensive aircraft measurements. Shaded areas correspond to the duration from take-off to landing of the ATR-42 aircraft. Flights indicated in black are the vertical exploration flights conducted in the vicinity of Niamey $\left(13^{\circ} 30^{\prime} \mathrm{N}, 02^{\circ} 05^{\prime} \mathrm{E}\right)$, on which results in the current study are based on. Date of the 2006 monsoon onset and the transitional period are depicted as defined by Janicot et al. (2008).

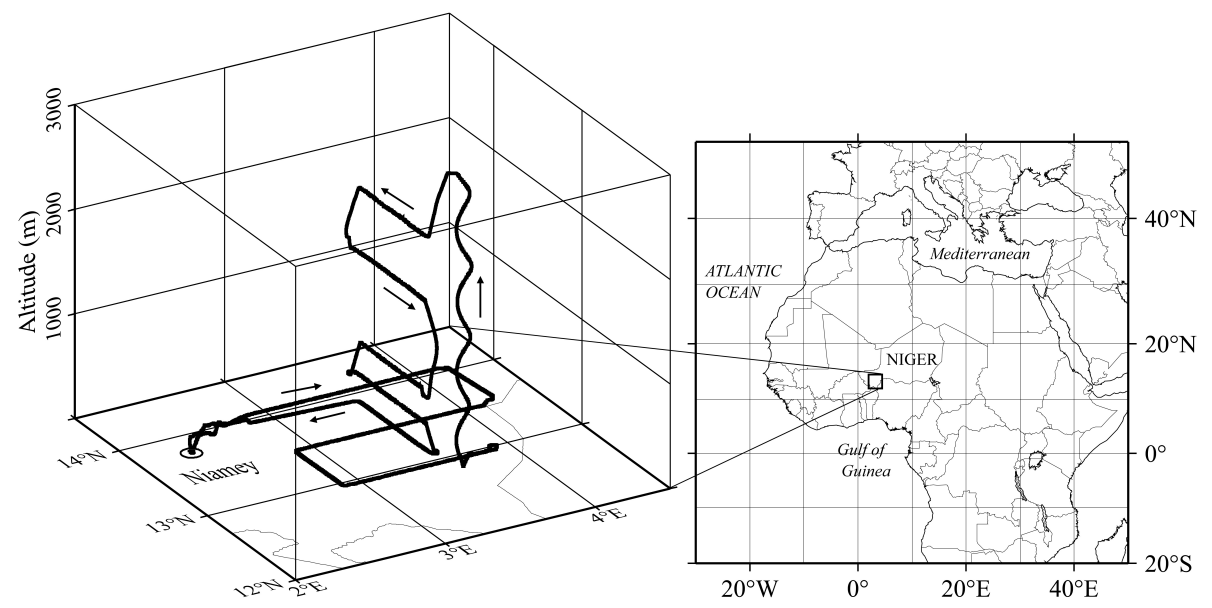

Fig. 2. Geographical location of the measurement area (right panel) and representative flight pattern (left panel) of stacked horizontal legs of the ATR-42 aircraft (from 5 August 2006).

Only during the final SOP in August when the monsoon was at its peak, a counterflow virtual impactor (CVI) was installed in addition to the CAI inlet for collecting cloud residual particles. The CVI (Ogren et al., 1985) is designed to exclusively collecting cloud elements (cloud droplets and ice crystals), while rejecting interstitial aerosol particles. The counterflow of the CVI was constantly adjusted to maintain the diameter of the cloud elements entering the probe to be $5 \mu \mathrm{m}$ (50\% collection efficiency) or larger. The subsequent evaporation of cloud elements in the particle free and dry return flow releases cloud residual particles. Further details on the CVI can be found elsewhere (Schwarzenboeck and Heintzenberg, 2000; Schwarzenboeck et al., 2000).

Thus, switching between the CVI in cloud and CAI in clear-sky conditions allowed measurement of either the cloud residual or total aerosol particles. Although frequent development and passage of MCS is observed over the studied area, for safety reasons, the ATR-42 and thus the CVI was operated only within relatively calm, shallow stratocumulustype clouds often encountered above the boundary layer. 


\subsection{Particle concentration and size distributions}

Measurements onboard ATR-42 involved particle sizing and counting by a scanning mobility particle spectrometer (SMPS) covering sizes $0.02<D p<0.3 \mu \mathrm{m}$, and an optical particle counter (OPC, GRIMM model 1.108) covering sizes $0.3<D p<2 \mu \mathrm{m}$. The SMPS was composed of a condensation particle counter CPC (TSI model 3010) and a differential mobility analyzer (DMA) as described by Villani et al. (2007). Collected data were combined to provide a continuous size distribution between 0.02 and $2 \mu \mathrm{m}$ every $2 \mathrm{~min}$. The size distributions measured during each SOP are presented in this report by grouping them into those measured within the "monsoon layer", "Saharan air layer (SAL)", and the "free troposphere" above the SAL. The mean distributions given for monsoon layer and SAL are based on averaging over $200-400$ spectra.

It must be noted that, SMPS and OPC work under different principles and are measuring different aerosol properties. Since there was no overlap of SMPS $(0.02<D p<0.3 \mu \mathrm{m})$ and OPC $(0.3<D p<2 \mu \mathrm{m})$ measured size ranges, OPC data are corrected using complex refractive indices of 1.528 $0.029 \mathrm{i}$ for the monsoon layer and $1.526-0.015 \mathrm{i}$ for the SAL layer (no correction was applied for the free troposphere) to take into account the OPC sensitivity to aerosol optical properties. The OPC size distribution data have been recalculated using Mie code (Bohren and Huffmann, 1983) for the above complex refractive indices. The above indices (for monsoon layer and SAL) have been deduced, using the complex refractive indices of chemical compounds determined by Raut and Chazette (2008) and the mass-linear internal mixing rule prescribed by Horvath (1998). After the correction, SMPS and OPC data were plotted together and were then fitted. The averaged data are simply plotted as they were, taking into account the recalculated OPC size spectra of monsoon and SAL layers.

Particles were most likely sized at relative humidities below the typical deliquescence points, thus the effect of particle growth on measured particle size is considered minimal. This was certainly the case for the SMPS having dried sheath air incorporated in the system. Also, by comparing ambient dew point temperature profiles with the measurement conditions in the onboard OPC, relative humidity in the instrument was estimated to remain below $50 \%$ in the lowest $1 \mathrm{~km}$ during all flights, and even lower for higher altitudes (e.g. RH less than $25 \%$ and $20 \%$ at $2 \mathrm{~km}$ and $3 \mathrm{~km}$, respectively). The decreasing trend is due to the larger gap between ambient and almost constant temperature in the aircraft cabin (approximately $35-38^{\circ} \mathrm{C}$ ). Furthermore, pressure inside the measurement lines resembled that of the ambient air conditions outside the aircraft.

In parallel, a second set of SMPS and OPC instruments measured sizes of particles that have been heated up to $285^{\circ} \mathrm{C}$ in a thermo-desorption column. When the non-heated spectrum is considered as "reference", comparison with the heated spectrum provides indirect information on the bulk aerosol composition. The instruments were cross-checked before the campaign in the laboratory, and the SMPS systems participated in EUSAAR (EUropean Supersites for Atmospheric Aerosol Research, http://www.eusaar.net/index.cfm) intercomparison workshops at IfT (Leibniz Institute for Tropospheric Research). Also, we inter-compared the pairs of SMPS and OPC without the thermo-desorption column before each flight, (thus, before starting to heat the column to $285^{\circ} \mathrm{C}$ ). We found that the spectra of the both SMPSs overlap fairly well and relative error was less than $10 \%$.

Particles consisting of sulfuric acid and other volatile compounds (e.g., ammonium nitrate, ammonium chloride), were found to evaporate at temperatures between 70 and $150^{\circ} \mathrm{C}$, typically at $100-110^{\circ} \mathrm{C}$ for sulfuric acid (Clarke et al., 1987 ; Pinnick et al., 1987; O'Dowd and Smith, 1993; Smith and O’Dowd, 1996; Cantrell et al., 1997; Kreidenweis et al., 1998). Ammonium sulfate and bisulfate were found to evaporate at temperatures between approximately $150{ }^{\circ} \mathrm{C}$ and $220^{\circ} \mathrm{C}$ (Clarke et al., 1987; Pinnick et al., 1987; Rood et al., 1987; O'Dowd and Smith, 1993; Hudson and Da, 1996; Smith and O'Dowd, 1996). Also, Nitrate (i.e., often in the form of $\mathrm{NH}_{4} \mathrm{NO}_{3}$ ) is found to be even more volatile than sulfate (Bassett and Seinfeld, 1984; Rood et al., 1985; O'Dowd and Smith, 1993). Thus, particles surviving after being heated to $285^{\circ} \mathrm{C}$ can be termed as those mostly made of refractory materials (e.g. sea salt, soot, mineral dust, some refractory organic carbon), otherwise the particles should be mainly composed of volatile species (e.g. sulfates, organic carbon, etc.). Possibility remains however, that some very volatile materials such as low molecule volatile organic compounds (VOC) may be lost during the transfer to the instruments already at the reference temperatures.

In addition, concentration of cloud condensation nuclei $(\mathrm{CCN})$ was measured using a static thermal gradient diffusion chamber (model 100-B, University of Wyoming). Details on the current $\mathrm{CCN}$ measurement can be found elsewhere (Crumeyrolle et al., 2008). In brief, CCN number concentrations were determined at supersaturations (SS) of $0.2,0.4,0.6,0.8$ and $1 \%$, providing one $\mathrm{CCN}$ spectrum every five minutes. A condensation particle counter (CPC, TSI model 3010) was monitoring total ambient aerosol concentration $(\mathrm{CN})$ for particles larger than $10 \mathrm{~nm}$. The combination of the two instruments provided the $\mathrm{CCN} / \mathrm{CN}$ ratio.

\subsection{Sampling and analysis}

In order to investigate the composition and mixing states of the particles, aerosol samples were directly collected using two-stage cascade impactors. The impactor type used in this study is basically identical to that described in Matsuki et al. $(2005 \mathrm{a}, \mathrm{b})$. The aerodynamic diameter at which particles are collected with $50 \%$ collection efficiency is found to be $1.6 \mu \mathrm{m}$ and $0.2 \mu \mathrm{m}$, respectively, at the first and second stage of the impactor with a flow rate of approximately $1.0 \mathrm{~L} \mathrm{~min}^{-1}$ 
$(1013 \mathrm{hPa}, 293 \mathrm{~K})$. This means in practice that supermicron particles are selectively found on the first stage due to the larger particle density found in the actual atmosphere (e.g. about $2.7 \mathrm{~g} \mathrm{~cm}^{-3}$ for dust particles), while those on the second stage are representative of the accumulation mode $(0.1<D p<1 \mu \mathrm{m})$ particles.

The frequency and duration of the individual samples taken during the flights has been a function of the flight patterns of every individual flight (with number and altitude of stacked horizontal flight legs). Typically, per flight, 2-6 samples were collected in different altitudes ranging from $0.4 \mathrm{~km}$ to $5 \mathrm{~km}$ a.s.1., each sample lasting $15-20 \mathrm{~min}$ (Fig. 2). For SOP2a2, few cloud residual samples were made via CVI in the presence of stratocumulus clouds.

Collodion film on a nickel support (MAXTAFORM Reference finder grid, type H7, 400 mesh) was chosen as the sampling substrate. After the flight, the particle-laden grids were kept sealed under dry condition $(\mathrm{RH}<40 \%)$ until they were analyzed in the laboratory on individual particle basis.

Morphology and elemental composition of individual particles were analyzed by a series of electron microscopes coupled to energy dispersive X-ray spectrometers. The samples were imaged firstly under a digitized transmission electron microscope (TEM, Hitachi H-7650) to obtain high resolution images of the particles. About 10 fields of view with constant magnification (at x3000 and x10000 for the first (coarse) and second (fine) stage, respectively) were imaged randomly over a sample at $120 \mathrm{kV}$ acceleration voltage.

Then, by following the references marked on the grids, the imaged particles collected on the first stage (i.e. coarse particles) were located again under a scanning electron microscope (SEM, JEOL, JSM-5910LV) coupled to an energy dispersive X-ray spectrometer (EDX, Princeton Gamma-Tech, Prism2000), and X-ray spectra were monitored from the individual coarse particles at $20 \mathrm{kV}$ acceleration voltage. The fine particles collected on the second stage (i.e. submicron particles) were analyzed under another TEM (JEOL2000FX) coupled to an EDX (TRACOR Northern 5502) operating at $200 \mathrm{kV}$. X-ray peaks of lighter elements such as C, $\mathrm{N}$ and $\mathrm{O}$ were not included in the quantification of the relative atomic ratio, due to the uncertainties caused by the significant absorption of low energy X-rays within the samples, and also by the fact that the collodion film substrate itself contains some $\mathrm{C}$ and $\mathrm{O}$.

In total, about 3600 (about 50 per sample) coarse particles were analyzed individually under SEM-EDX on manual basis, while 1000 (about 25 per sample) fine particles were analyzed by TEM-EDX. The smaller counts are due to more demanding manual identification and analysis of fine particles under TEM. Still, electron microscopy is a preferential tool for directly obtaining detailed information on the particle shape, elemental composition and mixing states.
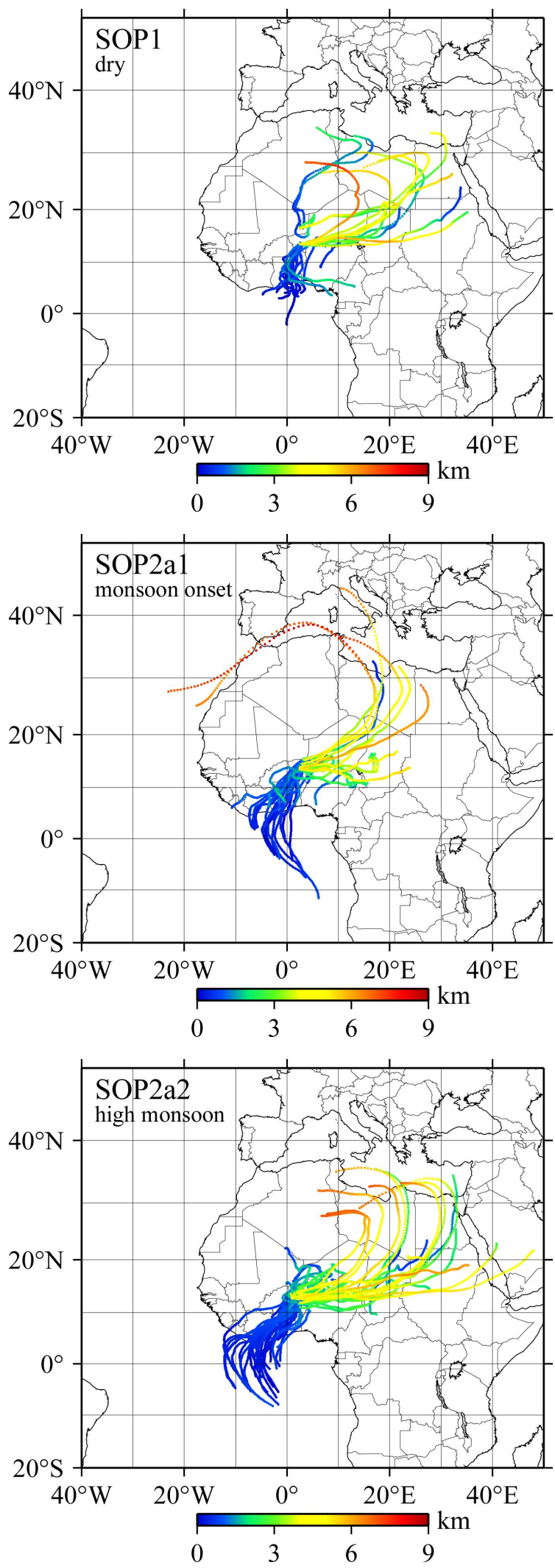

Fig. 3. Five-day backward trajectory calculations of air-masses arriving along the tracks of the ATR-42 aircraft during the three AMMA SOPs. 

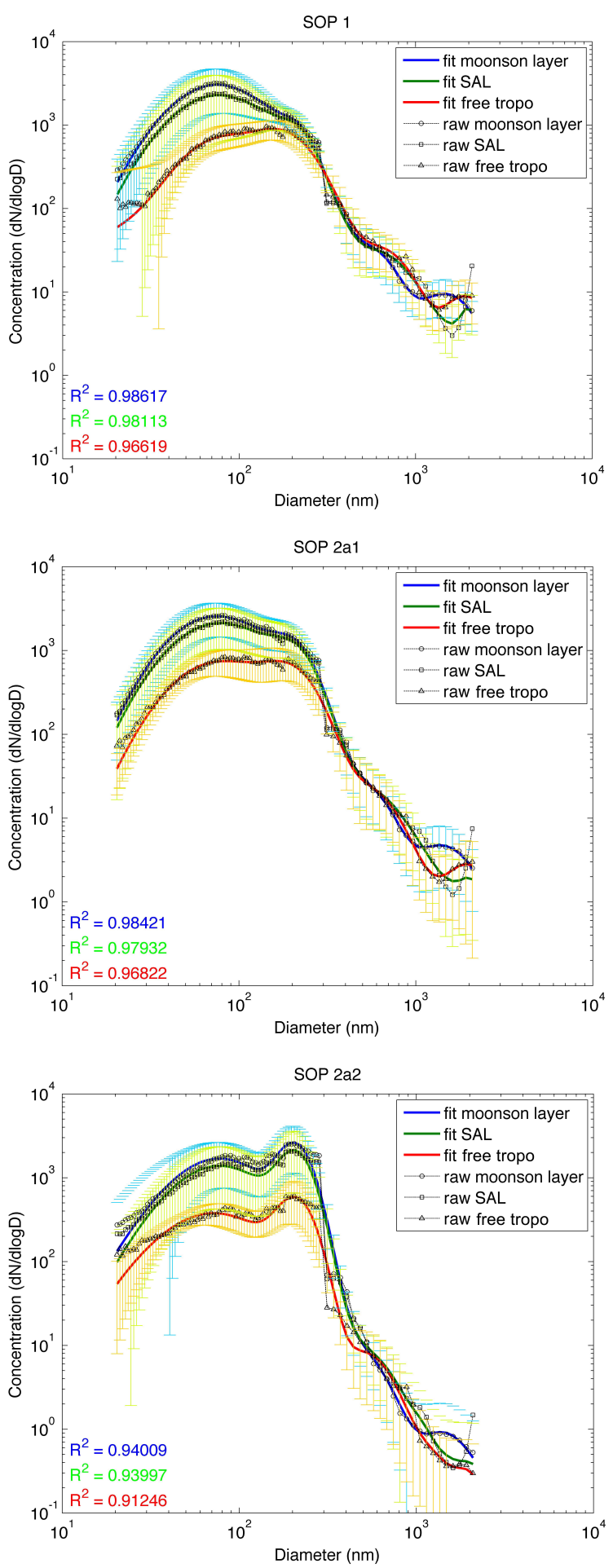

Fig. 4. Mean particle number size distributions observed in the monsoon layer, Saharan air layer (SAL), and free troposphere from vertical exploration of the atmosphere in the vicinity of Niamey during the three AMMA SOPs corresponding to "dry", "monsoon onset" and "high monsoon" periods. Error bars indicate 1 standard deviation. Open legends denote the averaged raw spectra and solid curves are the fitted log-normal size distributions.

\section{Results and discussion}

\subsection{Air-mass transport patterns}

In order to study the origin of the air-masses arriving at the aircraft measurement positions, 5-day backward trajectory calculations have been performed using METEX model developed by NIES-CGER (Zeng et al., 2003). At least 4-7 trajectories were calculated for each flight, depending on the number of stacked horizontal legs. Figure 3 shows the compilation of trajectories arriving at the aircraft measurement positions in the vicinity of Niamey during the three intensive observational periods SOP1, SOP2a1, SOP2a2.

A complete turnover of the wind regimes was typically found across an altitude of roughly $1500 \mathrm{~m}$ (transition between blue and green colors in Fig. 3). The transition between the monsoon flux and the Saharan air flow known as the Inter Tropical Discontinuity (ITD) on the ground surface was always located north of Niamey throughout the three SOPs (Canut et al., 2009). Thus, as it is evident in the airmass trajectories, the lowest part of the troposphere was most frequently occupied by the cool and moist monsoon flux approaching from south-west. The monsoon flux was progressively gaining strength and can be traced back to the Gulf of Guinea especially during SOP2a2. The layer of warm and dry Saharan air layer (SAL, or so-called Harmattan) was persistently arriving from east to north-east due to the presence of the African Easterly Jet (AEJ) along the semi-arid regions of the Sahel belt.

An important change identified between dry and subsequent monsoon periods through our aircraft soundings has been the decrease in vertical extent of the planetary boundary layer (PBL) due to the moistening of the ground by rainfall, and to the consumption of available energy by evaporation instead of PBL heating (Saïd et al., 2009). During the first two SOPs, as most of the flights were conducted during the middle of the day (Fig. 1), it was often the case that the PBL top (SOP1: 1600m; SOP2a1 1400m) had already reached the shear zone between the monsoon layer and SAL, hence the height of the wind rotation was typically found close to the PBL top or even below. Contrary to the first two SOPs, the PBL top during SOP2a2 $(850 \mathrm{~m})$ was often way below the shear height due to the decreasing PBL depth. According to the UHF observations by Kalapureddy et al. (2009) in Niamey in 2006, the shear height or the monsoon depth reached on average $1500 \mathrm{~m}$ before the monsoon onset, and dropped to $1200 \mathrm{~m}$ during the monsoon period. The wind rotation heights represented by the trajectories correspond rather well with the observed monsoon depth.

It is also worth noting that there was another wind regime (free troposphere) at even higher altitudes $(4-6 \mathrm{~km})$, where the air-mass arrived after making a descending anticyclonic turn around the Saharan high (Cook, 1999).

Thus, aerosol particles approaching the measurement points would have very different sources due to such abrupt 
Table 1. Parameters (number concentration $\left(\mathrm{n}_{i}\right)$, geometric standard deviation $\left(\sigma_{i}\right)$, and number median particle diameter $\left.\left(\mathrm{m}_{i}\right)\right)$ for the mean particle size distributions shown in Fig. 4, expressed as the sum of four log-normal modes.

\begin{tabular}{|c|c|c|c|c|c|c|c|c|c|c|c|c|c|}
\hline & & \multicolumn{4}{|c|}{ SOP1 (dry) } & \multicolumn{4}{|c|}{ SOP2a1 (monsoon onset) } & \multicolumn{4}{|c|}{ SOP2a2 (high monsoon) } \\
\hline & & $\mathrm{i}=1$ & $\mathrm{i}=2$ & $\mathrm{i}=3$ & $\mathrm{i}=4$ & $\mathrm{i}=1$ & $\mathrm{i}=2$ & $\mathrm{i}=3$ & $\mathrm{i}=4$ & $\mathrm{i}=1$ & $\mathrm{i}=2$ & $\mathrm{i}=3$ & $\mathrm{i}=4$ \\
\hline Monsoon Layer & $\begin{array}{l}\mathrm{n}_{i}\left(\mathrm{~cm}^{-3}\right) \\
\sigma_{i} \\
\mathrm{~m}_{i}(\mathrm{~nm})\end{array}$ & $\begin{array}{l}1651 \\
1.69 \\
73\end{array}$ & $\begin{array}{l}329 \\
1.32 \\
195\end{array}$ & $\begin{array}{l}9.9 \\
1.33 \\
555\end{array}$ & $\begin{array}{l}3.6 \\
1.46 \\
1473\end{array}$ & $\begin{array}{l}1471 \\
1.70 \\
74\end{array}$ & $\begin{array}{l}322 \\
1.32 \\
191\end{array}$ & $\begin{array}{l}6.3 \\
1.31 \\
550\end{array}$ & $\begin{array}{l}2.0 \\
1.48 \\
1400\end{array}$ & $\begin{array}{l}992 \\
1.68 \\
73\end{array}$ & $\begin{array}{l}510 \\
1.22 \\
197\end{array}$ & $\begin{array}{l}2.0 \\
1.35 \\
559\end{array}$ & $\begin{array}{l}0.3 \\
1.30 \\
1481\end{array}$ \\
\hline Saharan Air Layer (SAL) & $\begin{array}{l}\mathrm{n}_{i}\left(\mathrm{~cm}^{-3}\right) \\
\sigma_{i} \\
\mathrm{~m}_{i}(\mathrm{~nm})\end{array}$ & $\begin{array}{l}1303 \\
1.65 \\
75\end{array}$ & $\begin{array}{l}227 \\
1.32 \\
191\end{array}$ & $\begin{array}{l}10.6 \\
1.41 \\
627\end{array}$ & $\begin{array}{l}2.4 \\
1.54 \\
1930\end{array}$ & $\begin{array}{l}1213 \\
1.72 \\
76\end{array}$ & $\begin{array}{l}299 \\
1.33 \\
192\end{array}$ & $\begin{array}{l}6.9 \\
1.37 \\
588\end{array}$ & $\begin{array}{l}1.3 \\
1.66 \\
1695\end{array}$ & $\begin{array}{l}812 \\
1.70 \\
73\end{array}$ & $\begin{array}{l}421 \\
1.23 \\
199\end{array}$ & $\begin{array}{l}2.7 \\
1.35 \\
574\end{array}$ & $\begin{array}{l}0.3 \\
1.38 \\
1588\end{array}$ \\
\hline Free troposphere & $\begin{array}{l}\mathrm{n}_{i}\left(\mathrm{~cm}^{-3}\right) \\
\sigma_{i} \\
\mathrm{~m}_{i}(\mathrm{~nm})\end{array}$ & $\begin{array}{l}314 \\
1.49 \\
70\end{array}$ & $\begin{array}{l}309 \\
1.42 \\
161\end{array}$ & $\begin{array}{l}10.2 \\
1.31 \\
603\end{array}$ & $\begin{array}{l}3.1 \\
1.36 \\
1841\end{array}$ & $\begin{array}{l}421 \\
1.71 \\
75\end{array}$ & $\begin{array}{l}196 \\
1.37 \\
190\end{array}$ & $\begin{array}{l}7.7 \\
1.35 \\
557\end{array}$ & $\begin{array}{l}1.3 \\
1.47 \\
1688\end{array}$ & $\begin{array}{l}221 \\
1.62 \\
62\end{array}$ & $\begin{array}{l}126 \\
1.18 \\
181\end{array}$ & $\begin{array}{l}2.0 \\
1.21 \\
525\end{array}$ & $\begin{array}{l}0.2 \\
1.21 \\
1448\end{array}$ \\
\hline
\end{tabular}

changes in wind direction, and are expected to show strong seasonal and spatial variations depending on the arriving altitudes.

\subsection{Particle size distributions}

The overview of the particle number size distributions measured during the three SOPs is shown in Fig. 4. The size distributions in the particle diameter range of $0.02<D p<2 \mu \mathrm{m}$ measured by the SMPS and OPC in each SOP were grouped into those measured within the monsoon layer, Saharan air layer (SAL), and the free troposphere above the SAL. Since the trajectories arriving in the highest altitude range (4-6 km) showed markedly different (vertical) transport patterns as compared to those in SAL (Fig. 3), the related aerosol size distributions were averaged separately and denoted as those representing the "free troposphere".

The parameters of log-normal distributions fitting the mean number size spectra per SOP and per atmospheric layer explored with the ATR-42 are presented in Table 1. We have to note that averaging particle size distributions for similar air-mass backward trajectories (i.e. monsoon layer, SAL, or free troposphere), as presented here, gave minimum variabilities within corresponding size spectra. The variabilities were more pronounced, when categorizing the number size distributions according to constant altitude ranges (not presented here).

During SOP1 (dry period), a pronounced Aitken mode (centered around $D p=70-80 \mathrm{~nm}$ ) has been observed especially in the monsoon layer, besides a rather weak accumulation mode ( $D p$ around $200 \mathrm{~nm}$ ). This is in sharp contrast to the size distributions observed during SOP2a2 (high monsoon period), where the Aitken mode was less prominent and the accumulation mode centered between $D p=200$ $220 \mathrm{~nm}$ largely dominating over the Aitken mode (Fig. 4). Particle number size distributions observed in the transitional SOP2a1 (monsoon onset period) indeed showed intermedi-

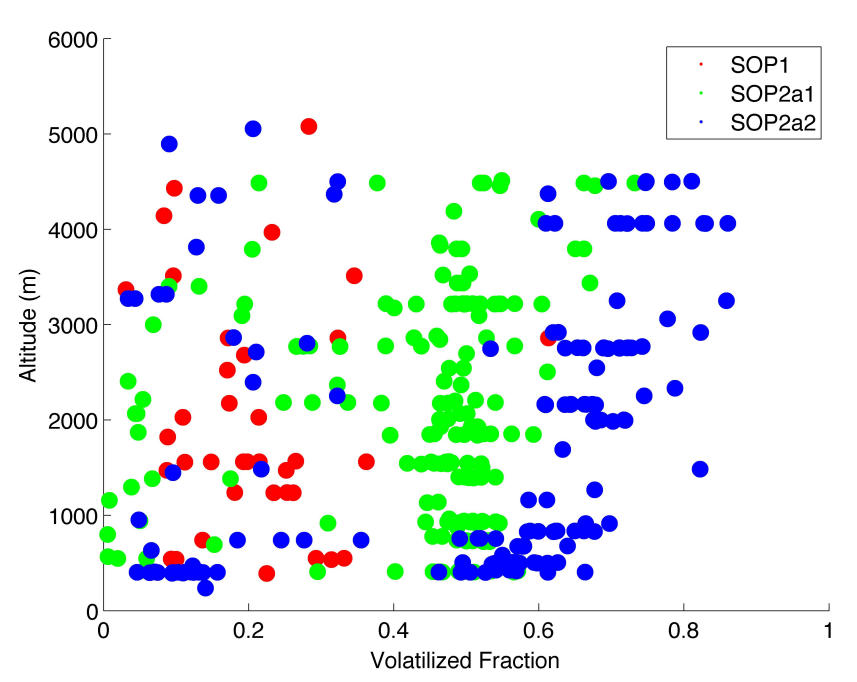

Fig. 5. Vertical profiles of volatilized volume fraction $\left(\left(\mathrm{V}_{\text {ref }}\right.\right.$ $\left.-\mathrm{V}_{285}\right) / \mathrm{V}_{\text {ref }}$ ) derived by comparing the reference and heated $\left(285^{\circ} \mathrm{C}\right)$ volume size distributions. The considered size range is limited to $20<D p<1000 \mathrm{~nm}$.

ate characteristics with respect to the two aerosol modes described above for adjacent periods SOP1 and SOP2a2.

\subsection{Particle volatility}

As mentioned in the experimental section, we were measuring number size distributions of particles heated up to $285^{\circ} \mathrm{C}$ in parallel with the size distributions at reference temperatures. If we then convert the two number size distributions into volume size distributions, the difference between the total volumes would then give the volatilized volume fraction $\left(\left(\mathrm{V}_{\text {ref }}-\mathrm{V}_{285}\right) / \mathrm{V}_{\text {ref }}\right)$. Higher values indicate that there is a larger fraction of volatile material in the total measured particle volume. 


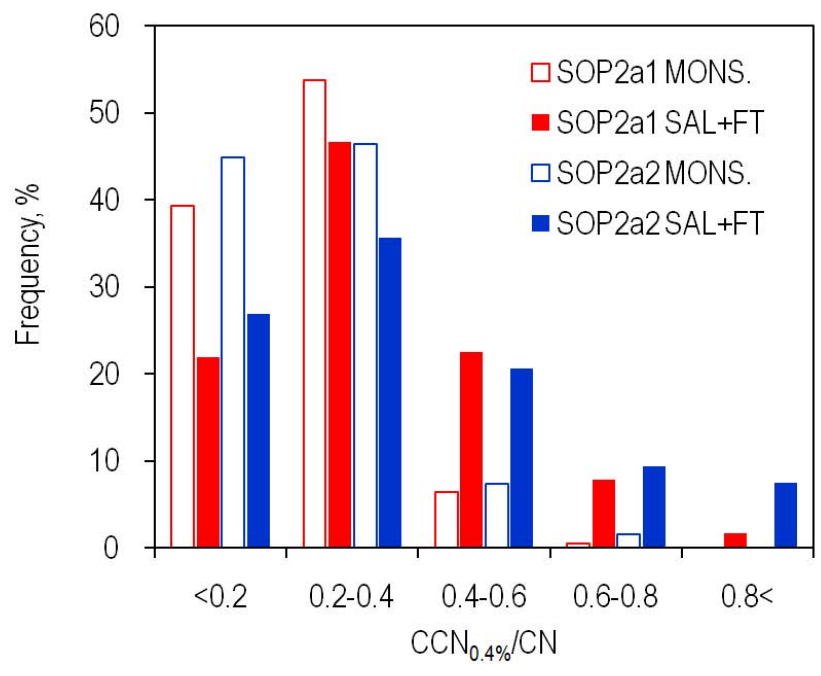

Fig. 6. Frequency distribution of various $\mathrm{CCN} / \mathrm{CN}$ ratios (at $0.4 \%$ super saturation) measured in different wind regimes $(\mathrm{SAL}+$ free troposphere vs. Monsoon layer) during SOP2a1 (monsoon onset period) and SOP2a2 (high monsoon period).

We plotted the volatilized fraction as a function of altitude in Fig. 5 for all the aircraft soundings performed during the three observational periods SOP1, 2a1, and 2a2. Each data point is represented by a corresponding pair of reference and heated spectra obtained every 2 min (duration of SMPS scans). We have to note that the integration of reference and volatilized particle volumes is limited here to the size range of $20-1000 \mathrm{~nm}$ in order to accentuate the volatilized fraction in the accumulation mode particles.

The major information that can be drawn from Fig. 5 is that submicrometer aerosol is much less volatile during SOP1 (dry season), as compared to SOP2a1 (monsoon onset) and SOP2a2 (high monsoon). The higher volatility of the aerosol after the onset of the monsoon seems to increase from SOP2a1 to SOP2a2. The volatile aerosol stems particularly from the $100-300 \mathrm{~nm}$ accumulation mode particles. Nevertheless, also during SOP2a1 and 2a2, a fraction of the particles seems to be as refractory as the largely non-volatile submicrometer aerosol population during SOP1.

Moderate volatility found during SOP2a1 (monsoon onset period) possibly reflects the intermediate mixing states undergoing seasonal transition from dry to monsoon period. It is worth emphasizing that the volatility was considerably small in the monsoon layer during SOP2a2 as compared to the overlying layers. If any different, then volatilized fraction in the monsoon layer during SOP2a1 also tended to be slightly smaller than that found in the SAL and free troposphere.

Based on the current volatility measurement, it is clear that there was a significant seasonal transition in the fraction of refractory materials contained in the fine particle population. Vertical distributions showed that volatilizing volumes do not significantly change with altitude during the first two SOPs, while it was considerably different during SOP2a2. Since the particle volatility shown in Fig. 5 is limited to $20-1000 \mathrm{~nm}$ range, this finding suggests that the fine particle composition may be significantly different between the monsoon layer and SAL especially during the wet period (SOP2a2).

The volatility behavior of aerosol particles in the size range $1-2 \mu \mathrm{m}$ did not show the same volatility trends as observed for submicrometer aerosol. Indeed, these supermicrometer particles are much more refractory with respect to temperature (and thus, less volatile) and show no clear trends when comparing periods SOP1, 2a1, and 2a2. The latter result is certainly due to the fact that supermicron particles are predominantly composed of non-volatile coarse mode mineral and sea salt particles. Detailed particle composition for the supermicron particles can be found elsewhere (Matsuki, 2010).

\subsection{CCN concentration}

At a first glance, the cloud nucleating properties are controlled by particle size and by the amount of soluble material contained in the particles or coating the particles. The range of $\mathrm{CCN}_{0.4 \%} / \mathrm{CN}$ ratios $(\mathrm{CCN}$ concentration relative to total $\mathrm{CN}$ concentration at $0.4 \%$ supersaturation) measured in the different wind regimes (SAL \& free troposphere vs. Monsoon layer) during SOP2a1 (monsoon onset period) and SOP2a2 (high monsoon period) are summarized in Fig. 6 (Note that the $\mathrm{CCN}$ chamber was not onboard the aircraft during the dry period). Higher $\mathrm{CCN} / \mathrm{CN}$ ratio indicates that there were more $\mathrm{CCN}$ active particles in the entire particle population $(D p>10 \mathrm{~nm})$.

Moderate values of $\mathrm{CCN} / \mathrm{CN}$ ratios were typically found in the monsoon layer during both periods, with about $90 \%$ of the data points within the range $\mathrm{CCN} / \mathrm{CN}<0.4$. Higher ratios were more frequently found in the overlying SAL and free troposphere. In particular, the data points in the range $\mathrm{CCN} / \mathrm{CN}>0.4$ accounted for nearly $40 \%$ of all measurements in the SAL \& free troposphere during SOP2a2 (high monsoon period), including some points even in the range $\mathrm{CCN} / \mathrm{CN}>0.8$.

As it is evident in the evolution of particle size distributions (Fig. 4), we saw progressive shift from Aitken mode dominant spectra into accumulation mode dominant spectra in all altitudes as we proceed from dry period SOP1 to the SOP2a2 period of fully developed monsoon. Thus, the increased number fraction of larger particles in $\mathrm{CCN}$ relevant sizes may be solely responsible for the comparably high $\mathrm{CCN} / \mathrm{CN}$ ratios observed during SOP2a2. To verify this, we plotted in Fig. 7 the relationship between CCN/CN ratios (at $0.4 \%$ super saturation) against number fraction of particles in $\mathrm{CCN}$ relevant sizes $\left(\mathrm{CN}_{101-288 \mathrm{~nm}} / \mathrm{CN}\right)$. We consider particles larger than $100 \mathrm{~nm}$ to be the representative CCN fraction. The total number of particles within the $101-288 \mathrm{~nm}$ size range was extracted from the SMPS 

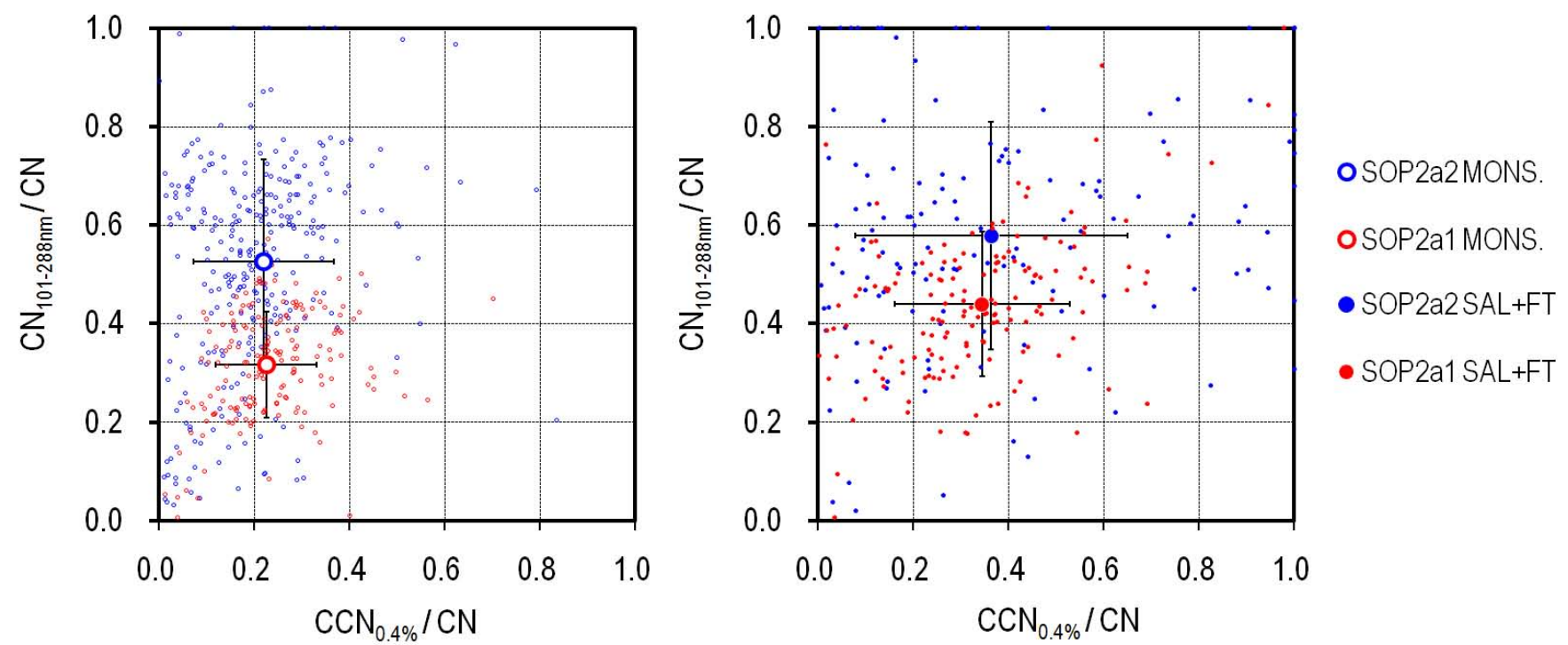

Fig. 7. Relationship between $\mathrm{CCN} / \mathrm{CN}$ ratio (at $0.4 \%$ super saturation) vs. number fraction of particles in $\mathrm{CCN}$ relevant sizes $(101<D p<$ $288 \mathrm{~nm}$ ) over total $\mathrm{CN}$ concentration. Average plots representing the 4 different populations are shown in larger circles and the error bars indicate 1 standard deviation.

measurement and compared against the total $\mathrm{CN}$ concentration measured by the CPC counter (TSI model 3010) to obtain the ratio $\mathrm{CN}_{101-288 \mathrm{~nm}} / \mathrm{CN}$.

In the monsoon layer, $\mathrm{CCN} / \mathrm{CN}$ ratios were mostly confined to the range $<0.4$ both during SOP2a1 and SOP2a2 as we saw in Fig. 6. However, there was a rather distinct difference between the two periods in terms of the number fraction of larger particles $\left(\mathrm{CN}_{101-288} / \mathrm{CN}\right)$. This can be interpreted such that there may be less $\mathrm{CCN}$ active particles during SOP2a2 despite the increased number of particles in the $\mathrm{CCN}$ relevant sizes.

In the overlying SAL and free troposphere, there is significant scatter in the plot and the difference between the two periods is less distinct as compared to the monsoon layer. Still, it is noteworthy that many data points $(40 \%)$ are found beyond the ratio $\mathrm{CCN} / \mathrm{CN}>0.4$, especially during SOP2a2. This is an indication that the particles in the SAL and free troposphere were more frequently occupied by $\mathrm{CCN}$ active particles. The increased $\mathrm{CCN} / \mathrm{CN}$ fraction may partly be attributed to the increased fraction of particles in $\mathrm{CCN}$ relevant sizes, however, the range of observed $\mathrm{CN}_{101-288} / \mathrm{CN}$ ratios was not particularly higher in SAL, again highlighting the difference between the monsoon layer and overlying layers especially during SOP2a2.

From the plots in Fig. 7, we can crudely deduce that the particles in the monsoon layer during SOP2a2 have been relatively hydrophobic (at least less hygroscopic), whereas those in the SAL and free troposphere have been more hygroscopic. Interestingly, the volatility profiles (Fig. 5) also showed higher values especially in SAL during SOP2a2 (high monsoon period). Such coincidence between the par- ticle volatility and $\mathrm{CCN}$ activity suggests that the volatilized material is at the origin of the enhanced hygroscopicity of the particles. The above observations indicate that the particles transported in the SAL layer during SOP2a2 were particularly $\mathrm{CCN}$ active (i.e. large and hygroscopic).

\subsection{Particle identification}

Particles collected by the two-stage impactor were later analyzed on individual particle basis under electron microscopes (SEM and TEM) coupled to EDX system to study what exactly have been the chemistry and mixing states of the measured particles.

Coarse (thus supermicron) particles collected on the first stage of the impactor were analyzed by SEM-EDX. In general, these coarse particles were dominated by dust particles. Significant number of sea salt particles appeared only during SOP2a2 within the prevailing monsoon flux where the air mass can be traced back to the gulf of Guinea (Fig. 3). An internal mixture of the two species was hardly found. Details on the coarse particle analysis and results can be found in a companion paper (Matsuki et al., 2010).

Here, we put more emphasis on the accumulation mode particles collected on the second stage of the impactor and analyzed under TEM-EDX, since they constitute an important fraction of the aerosol by number, and are hence relevant for studying radiative effects and $\mathrm{CCN}$ properties of aerosol populations as a whole.

The accumulation mode particles found in the current study can be distinguished as those consisting roughly of the following three aerosol types: mineral dust, biomass burning, and sulfate particles. Representative electron micrographs 

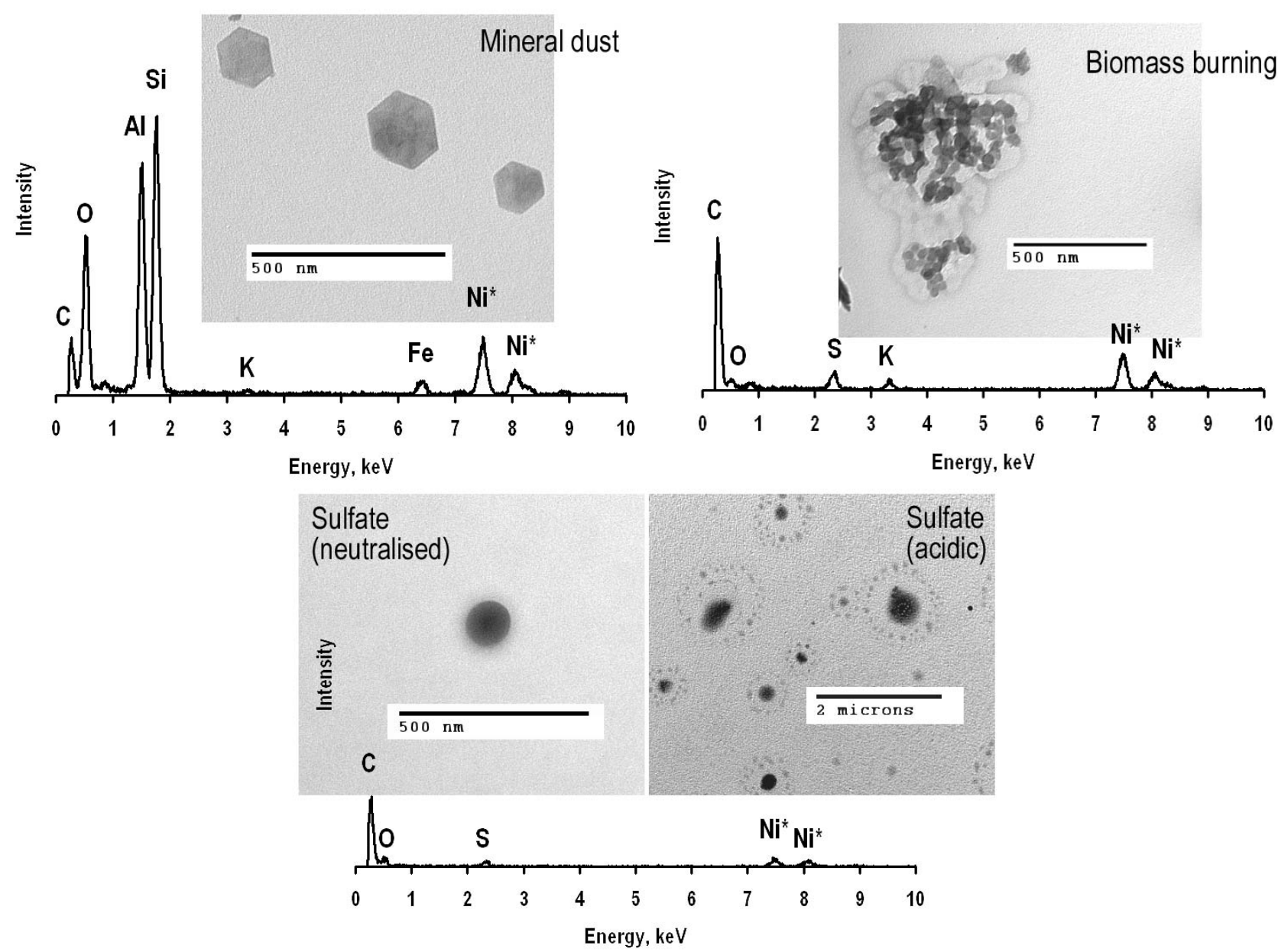

Fig. 8. Electron micrograph and X-ray spectrum of representative submicron particles collected through the AMMA 2006 campaign over West Africa. Peaks of Nickel come from the Ni support, while Carbon and Oxygen are partly from collodion film used as the substrate.

and X-ray spectra can be found in Fig. 8. Other minor species included sea salt like particles, carbonaceous particles either in typical chain-like aggregate of soot particles or those giving only the X-ray peak of C. Dust particles can be distinguished as aluminosilicate clay minerals. Most of these particles showed characteristic morphology in the form of hexagonal flakes, and abundance in $\mathrm{Al}$ and $\mathrm{Si}$ elements, $35 \%$ of which can be identified as particles made of kaolinite since no other element such as $\mathrm{Na}, \mathrm{Mg}, \mathrm{K}, \mathrm{Ca}$ was detected. For the remaining fractions, it was difficult to distinguish the mineral species from the morphology and elemental composition, and thus, illite, chlorite or montmorillonite remain as the likely candidates.

Although biomass burning particles may sometimes resemble ammonium sulfate particles in morphology, they often contain $\mathrm{K}$ in addition to $\mathrm{S}$. Although $\mathrm{C}$ and $\mathrm{O}$ should make an important fraction of such particles supposedly composed of organic compounds, due to the difficulties related to the quantification of such lighter elements, we relied on the combination of $\mathrm{K}$ and $\mathrm{S}$ (or $\mathrm{Cl}$ ) as evidence for the biomass burning origin. Although $\mathrm{K}$ in fine particle fraction not attributable to mineral dust or sea salt can be regarded as an indicator of biomass burning (Andreae, 1983), there may be a slight chance that the number of biomass burning particles is overestimated since some non-smoke sulfate may also contain $\mathrm{K}$ (e.g. fossil fuel burning and waste incineration).

Many of the biomass burning particles tended to evaporate after the strong electron irradiation, often leaving soot (chain-like aggregates) inclusions behind (Fig. 8). Roughly $40-50 \%$ of the biomass burning particles contained such inclusions. Since biomass burning particles are initially rather stable under the electron beam (Pósfai et al., 2003), such susceptibility against the electron beam suggests presence of volatile organic acids or significant mixing with sulfate which may also be related to the observed particle volatility (Fig. 5). It must be noted that, if any, there was very little evidence that supports the assumption of an internal mixing between mineral dust and biomass burning particles. The two components were found predominantly in external mixtures throughout the three periods. 
Electron-transparent spherical particles enriched in $\mathrm{S}$ can be termed as sulfate particles. Absence of satellite structure (or droplet rings) typically found with sulfuric acid droplets or ammonium bisulfate particles (Bigg, 1980) is an indication that they are neutralized most probably by ammonium. Sulfate particles with satellite structure were spotted only in the maritime air-mass over the gulf of Guinea, during which the aircraft made several southerly excursions to Cotonou, Benin $\left(6^{\circ} 22^{\prime} \mathrm{N}, 2^{\circ} 25^{\prime} \mathrm{E}\right)$. Otherwise, sulfate particles over the Sahel region in the vicinity of Niamey typically showed more neutralized features. Sulfate particles also tend to evaporate under strong electron irradiation, suggesting closer link with the observed volatility.

The relative abundance of the major particle types is summarized in Fig. 9. All analyzed particles were grouped into those collected within monsoon layer and overlying layers (SAL + free troposphere), and the abundance of each particle type was compared between the three periods. To show the range of uncertainties in the counting statistics resulting from the limited number of analyzed particles, 95\% confidence intervals (Weinbruch et al., 2002) were calculated and given in Fig. 9.

During the dry season (SOP1), mineral dust was the predominant particle group in the accumulation mode particles in all altitudes. Then, the fraction of dust particles dropped continuously during the following two SOPs (monsoon onset and high monsoon periods). This decrease in the fraction of mineral dust particles was compensated by the prevailing biomass burning and sulfate particles.

The relative abundances of the three particle groups were rather similar between the monsoon layer and overlying layers (SAL and free troposphere) during the first two SOPs (dry and monsoon onset). Then, there was a marked drop in the dust fraction especially in the monsoon layer during SOP2a2, which is compensated by the exceptionally large fraction of biomass burning particles.

The results of the single particle analysis (Fig. 9) are in very good agreement with the study of physical properties such as the particle volatility (Fig. 5). The low volatilized fractions $(<0.4)$ observed during SOP1 (dry period) are consistent with the dominance of the non-volatile submicron dust particles both in the monsoon layer and SAL. Whereas large compositional difference between the monsoon layer and SAL as suggested by the particle volatility measurements during SOP2a2 (Fig. 5) also is confirmed by the remarkably large fraction of biomass burning particles in the monsoon flux (Fig. 9).

\subsection{Particle mixing states and hygroscopicity}

As mentioned previously in Sect. 3.4, the $\mathrm{CCN} / \mathrm{CN}$ ratio (Fig. 6) was unexpectedly low in the monsoon layer during SOP2a2 despite the increased number of particles in CCN relevant sizes (Fig. 4). The monsoon layer was found to be associated with the smallest contributions of mineral dust

\section{SAL \& free troposphere}

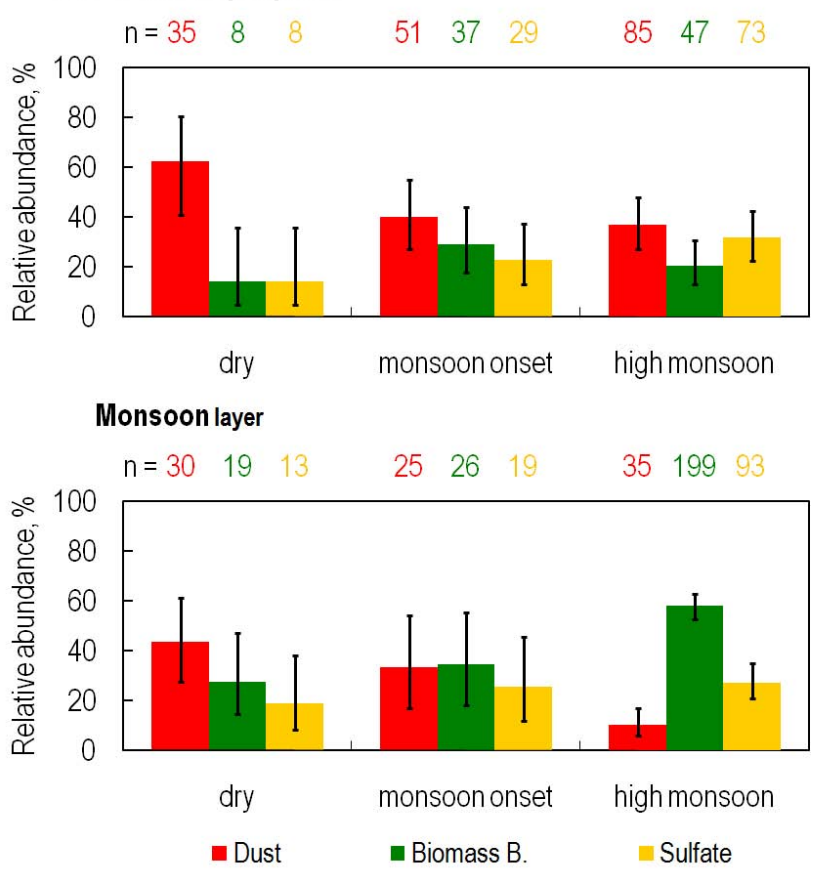

Fig. 9. Relative abundances of mineral dust, biomass burning, and sulfate fractions in submicron particles (Fig. 8) collected in SAL (+ free troposphere) and monsoon layer during the three SOPs. Error bars indicate $95 \%$ confidence intervals. Numbers of analyzed particles by TEM-EDX are indicated in corresponding colors.

fraction (Fig. 9). Mineral particles are generally considered as "more insoluble" particles. Instead, largest fractions of biomass burning particles were found in these altitudes. The highest range of $\mathrm{CCN} / \mathrm{CN}$ ratio was found rather in the overlying SAL and free troposphere during SOP2a2, where the contribution of mineral dust was even larger as compared to monsoon layer (Fig. 9).

To interpret our findings, experimental evidence can be found, which proves that freshly produced biomass burning particles can be rather hydrophobic, whereas atmospheric aging turns them into more hygroscopic particles. Kotchenruther and Hobbs (1998), for example performed direct measurements of the hygroscopicity of smoke particles in Brazil, and observed extremely low hygroscopic growth of fresh smoke particles. They also showed increased growth for more aged smoke plumes unaffected by other species. This can be attributed to the secondary production of more hygroscopic species such as sulfate.

Similarly, freshly produced biomass burning aerosol in the Amazonian basin was shown to be dominated by nearly hydrophobic particles at all sizes (growth factor $<1.2$ ), and the atmospheric processing gradually converted particles to be moderately hygroscopic (Rissler et al., 2006). Highly aged biomass burning plumes from Africa transported over the Atlantic showed all particles to be highly hygroscopic (growth 


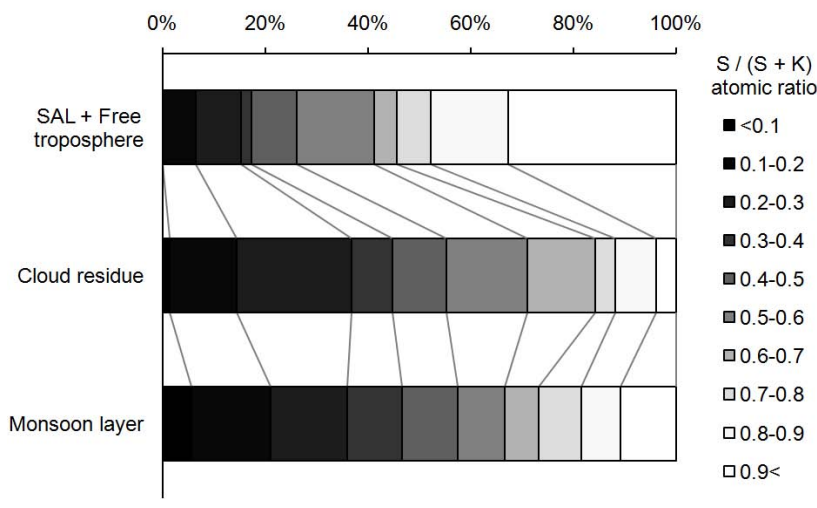

Fig. 10. Variations in atomic ratio (or molar ratio) of $S$ relative to $K$ found within individual biomass burning particles collected during SOP2a2 (monsoon period).

factor $>1.2$ ), indicating the accumulation of secondary soluble components (Maßling et al., 2003). Other processes leading to the enhanced hygroscopicity of initially hydrophobic organic particles may include conversion of large organic compounds into simpler organic acids via aging (Gao et al., 2003).

Mass fraction of potassium can be used as a good indicator for the aging of smoke particles, since aged smoke particles show enrichment of species associated with secondary aerosol production such as sulfur in the form of sulfate (Reid et al., 2005). Freshly emitted biomass burning particles are reported to contain more $\mathrm{Cl}$ and its replacement by $\mathrm{S}$ can be recognized as the sign of aging in the atmosphere ( $\mathrm{Li}$ et al., 2003; Mouri et al., 1996). In order to compare the degree of aging, the range of atomic ratios (S element relative to $\mathrm{K}$ ) found within individual biomass burning particles collected during SOP2a2 are summarized in Fig. 10.

Figure 10 shows that nearly half of the total biomass burning particles collected in the SAL and free troposphere had very high $\mathrm{S}$ to $\mathrm{K}$ atomic ratios $(\mathrm{S} /(\mathrm{S}+\mathrm{K})>0.8)$, indicating significant secondary production of sulfate. On the contrary, more than half of the biomass burning particles collected within the monsoon layer had $\mathrm{S} /(\mathrm{S}+\mathrm{K})<0.5$, strongly indicating that many of them were still relatively fresh. The presence of relatively fresh biomass burning particles in the monsoon layer may as well be inferred from the particle volatility measurements (Fig. 5). Fresh biomass burning particles should in principal show smaller volatilized particle volumes as compared to the aged ones. This is because fresh particles contain much less secondary organic acids (e.g. oxalate, formate, acetate) or secondary inorganic species (e.g. ammonium, sulfate, nitrate), as compared to aged ones (Reid et al., 2005). The volatilized volume is largely dependent on the abundance of such secondary species. Therefore, small volatilized volume fractions observed in the monsoon layer provide further indication that the dominant biomass burning particles were still relatively fresh.
Thus, it is suggested that the rather low $\mathrm{CCN} / \mathrm{CN}$ ratio observed in the monsoon layer during SOP2a2 may be attributed to the predominance of relatively fresh biomass burning particles, which are assumed to be less hygroscopic. On the other hand, the highest values of $\mathrm{CCN} / \mathrm{CN}$ ratios observed in the SAL and free troposphere during SOP2a2 are most likely due to the dominance of sulfate and aged biomass burning particles (Figs. 9 and 10), together comprising the increasingly prominent accumulation mode particles (Fig. 4) (i.e. more hygroscopic particles in the $\mathrm{CCN}$ relevant sizes).

Seen the significant fraction of mineral dust particles in the SAL and free troposphere during SOP2a2, it becomes evident that there is increased potential for submicron dust particles to act as CCN upon the activation of liquid clouds (Twohy et al., 2009).

It is worth pointing out that we have also collected cloud residual particles using the CVI inlet during the passage through the stratocumulus clouds often encountered on top of the monsoon layer with overlying SAL. We did find submicron aluminosilicate mineral dust in our cloud residual particles, along with biomass burning and sulfate particles. Small inclusions of soluble components may potentially induce activation of the supposedly insoluble dust particles (Kelly et al., 2007; Levin et al., 1996). If we compare the detection frequencies of elements between the clear-sky dust particles with that of cloud residues, we observed a slight enrichment of elements such as $\mathrm{Na}, \mathrm{Mg}, \mathrm{S}, \mathrm{K}$, and $\mathrm{Ca}$ within clouds. These elements may have facilitated their initial activation.

\section{Conclusions}

In order to characterize the seasonal and spatial variations in the aerosol physico-chemical properties (particle size distributions, shape, composition, mixing state, hygroscopcity) undergoing transition from dry to wet seasons over West Africa, a series of physical and chemical analyses were conducted onboard the ATR-42 research aircraft deployed over Niamey, Niger in summer 2006 during the three special observation periods SOP1, SOP2a1, SOP2a2 of the AMMA project.

The observations showed a notable seasonal transition from Aitken mode dominant size distributions (SOP1) to the accumulation mode dominant spectra (SOP2a2) following the transition from dry period to the fully developed monsoon season. The combination of volatility spectra and single particle analysis revealed dominance of mineral dust (aluminosilicate) even in the submicron particle size range during SOP1 (dry period) in all altitudes. The mineral dust fraction gradually decreased as the season changed from dry to monsoon period, and eventually the biomass burning and sulfate particles together became dominant. Particle composition was relatively similar between monsoon layer and overlying layers (SAL and free troposphere) during SOP1 (dry period) 
and SOP2a1 (monsoon onset), but was considerably different during SOP2a2 (high monsoon).

The fraction of particles being able to act as $\mathrm{CCN}$ represented by $\mathrm{CCN} / \mathrm{CN}$ ratios showed marked differences between the monsoon layer and SAL, especially during SOP2a2, which could not be explained solely by the increased number of particles in CCN relevant sizes. Elemental composition suggested that the predominant biomass burning particles in the monsoon layer to be relatively fresh. The unexpectedly low CCN/CN ratios found in this layer could be attributable to the supposedly hydrophobic nature of fresh biomass burning particles.

In contrast, relatively high $\mathrm{CCN} / \mathrm{CN}$ ratios found in the SAL and free troposphere especially during SOP2a2 can be explained by the combination of increased fraction of accumulation mode particles, as well as dominance of more hygroscopic sulfate and aged biomass burning particles therein. Presence of submicron mineral dust particles were confirmed within the actual cloud residues co-existing with sulfate and biomass burning residual particles, suggesting their active role in the water-cloud activation.

A remaining question then is, how to explain that the particle chemistry was rather similar in the monsoon layer and overlying layers during the first two SOPs and considerably different during the final SOP. This is most likely linked with the boundary layer dynamics. The major change in the boundary layer dynamics identified through the dry and monsoon periods by our aircraft soundings was a decrease in planetary boundary layer (PBL) depth due to the moistening of the ground by rainfall, and to the consumption of available energy by evaporation instead of PBL heating. When the PBL is sufficiently energetic to incorporate some air from the SAL by entrainment, it generates drier, descending air parcels, described also as 'dry tongues' by Canut et al. (2009).

Detailed meteorological measurements simultaneously performed onboard the ATR-42 research aircraft yielded strong decreasing trends in the entrainment flux ratio (Saïd et al., 2009; Canut et al., 2009), which indicated that there was a strong interaction between the PBL and SAL with active entrainment during the first two SOPs. This explains the rather homogeneous aerosol compositions found between the two wind regimes during the first two SOPs. In the contrary, cloud layers tend to often disconnect PBL and SAL, resulting in the notably different particle compositions between the two layers, in particular the aging stages of the biomass burning particles.

Although, we couldn't detect features that can be directly linked to urban pollution, we cannot entirely exclude the possibility that at least some of the particles come from the major coastal cities in West Africa (e.g. Abidjan, Accra, Cotonou, Lagos, Lome) since the accelerated monsoon flux and decoupling of SAL and PBL during SOP2a2 together might favor more direct transport of particles from the coastal regions. At the same time, there is a significant zonal variability in the land cover along the monsoon flux (forests, savanna, cropland and Sahel) and multiple processes may be responsible for the production of the observed biomass burning particles (e.g. savanna and forest fires, agricultural burning or household emissions).

Finally, the $\mathrm{S}$ to $\mathrm{K}$ molar ratios among the individual biomass burning particles found as cloud residues were more or less close to that found in the monsoon layer rather than in SAL and free troposphere (Fig. 10). This could be an implication that the particles in the monsoon layer may predominantly be the source of $\mathrm{CCN}$ (despite the lower CCN/CN ratio) in the observed stratocumulus clouds encountered on top of the monsoon layer with overlying SAL. It is difficult to draw any firm conclusion from the limited number of cloud samples and analyzed particles therein, and the question as to how the particles from different layers (monsoon, SAL and free troposphere) contribute to the activation of such stratocumulus clouds, and eventually in the formation of MCS, remains to be studied in more detail.

Acknowledgements. Based on a French initiative, AMMA was built by an international scientific group and is currently funded by a large number of agencies, especially from France, UK, US and Africa. It has been the beneficiary of a major financial contribution from the European Community's Sixth Framework Research Programme. Detailed information on scientific coordination and funding is available on the AMMA International web site http://www.amma-international.org. This work was funded by the French API-AMMA, CNES, INSU, and the Japan Society for the Promotion of Science. We thank all the staff and pilots of the SAFIRE (Service des Avions Français Instruments pour la Recherche en Environnement, Toulouse) group for their help and support. We are grateful for the extraordinary instrumental preparation and operation by O. Laurent, G. Momboisse, and T. Bourrianne. We also thank J.-M. Henot. and B. Devouard of LMV (Laboratoire Magmas et Volcans, Clermont-Ferrand), C. Drégnaux and C. Szczepaniak of CICS (Centre Imagerie Cellulaire Santé, Clermont-Ferrand), S. Nitsche, D. Chaudanson, O. Grauby, D. Vielzeuf, A. Baronnet, D. Ferry, of CRMCN (Centre de Recherche en Matière Condensée et Nanosciences, Marseille), for their generous assistance in realizing the single particle analysis.

Edited by: P. Formenti

\section{References}

Andreae, M. O.: Soot carbon and excess fine potassium: Longrange transport of combustion-derived aerosols, Science, 220, 1148-1151, 1983.

Bassett, M., Seinfeld, J. H.: Atmospheric equilibrium model of sulfate and nitrate aerosols-II. Particle size analysis, Atmos. Environ., 18, 1163-1170, 1984.

Bigg, E. K.: Comparison of aerosol at four baseline atmospheric monitoring stations (Alaska, Hawaii, Tasmania, Antarctica), J. Appl. Meteor., 19, 5, 521-533, 1980.

Bond, T. C., Streets, D. G., Yarber, K. F., Nelson, S. M., Woo, J.H., and Klimont, Z.: A technology-based global inventory of 
black and organic carbon emissions from combustion, J. Geophys. Res., 109, D14203, doi:10.1029/2003JD003697, 2004.

Bohren, C. F. and Huffman, D. R.: Absorption and Scattering of Light by Small Particles, John Wiley, New York, 530 pp., 1983.

Cantrell, C. A., Zimmer, A., and Tyndall, G. S.: Absorption crosssections for water vapor from $183 \mathrm{~nm}$ to $193 \mathrm{~nm}$, Geophys. Res. Lett., 24, 2195-2198, 1997.

Canut, G., Lothon, M., Saïd, F., and Lohou, F.: Observation of entrainment at the interface between monsoon flow and the Saharan Air Layer, Q. J. Roy. Meteorol. Soc., Wiley InterScience, (www.interscience.wiley.com), doi:10.1002/qj.471, 2009.

Capes, G., Johnson, B., McFiggans, G., Williams, P. I., Haywood, J., and Coe, H.: Aging of biomass burning aerosols over West Africa: Aircraft measurements of chemical composition, microphysical properties, and emission ratios, J. Geophys. Res., 113, D00C15, doi:10.1029/2008JD009845, 2008.

Chou, C., Formenti, P., Maille, M., Ausset, P.. Helas, G., Harrison, M., and Osborne, S.: Size distribution, shape, and composition of mineral dust aerosols collected during the African Monsoon Multidisciplinary Analysis Special Observation Period 0: Dust and Biomass-Burning Experiment field campaign in Niger, January 2006, J. Geophys. Res., 113, D00C10, doi:10.1029/2008JD009897, 2008.

Christopher, S. A., Gupta, P., Haywood, J., and Greed, G.: Aerosol optical thicknesses over North Africa: 1. Development of a product for model validation using Ozone Monitoring Instrument, Multiangle Imaging Spectroradiometer, and Aerosol Robotic Network, J. Geophys. Res., 113, D00C04, doi:10.1029/2007JD009446, 2008.

Clarke, A. D., Ahlquist, N. C., and Covert, D. S.: The Pacific marine aerosol: Evidence for natural acid sulphates, J. Geophys. Res., 92(D4), 4179-4190, 1987.

Cook, K. H.: Generation of the African Easterly Jet and its role in determining West African precipitation, J. Clim., 12, 1165-1184, 1999.

Crumeyrolle, S., Gomes, L., Tulet, P., Matsuki, A., Schwarzenboeck, A., and Crahan, K.: Increase of the aerosol hygroscopicity by cloud processing in a mesoscale convective system: a case study from the AMMA campaign, Atmos. Chem. Phys., 8, 6907-6924, doi:10.5194/acp-8-6907-2008, 2008.

Formenti, P., Rajot, J. L., Desboeufs, K., Caquineau, S., Chevaillier, S., Nava, S., Gaudichet, A., Journet, E., Triquet, S., Alfaro, S., Chiari, M., Haywood, J., Coe, H., and Highwood, E.: Regional variability of the composition of mineral dust from western Africa: Results from the AMMA SOP0/DABEX and DODO field campaigns, J. Geophys. Res., 113, D00C13, doi:10.1029/2008JD009903, 2008.

Gao, S., Hegg, D. A., Hobbs, P. V., Kirchstetter, T. W., Magi, B. I., and Sadilek, M.: Water-soluble organic components in aerosols associated with savanna fires in southern Africa: Identification, evolution, and distribution, J. Geophys. Res., 108 (D13), 13, 8491, doi:10.1029/2002JD002324, 2003.

Haywood, J. M., Pelon, J., Formenti, P., Bharmal, N., Brooks, M., Capes, G., Chazette, P., Chou, C., Christopher, S., Coe, H., Cuesta, J., Derimian, Y., Desboeufs, K., Greed, G., Harrison, M., Heese, B., Highwood, E. J., Johnson, B., Mallet, M., Marticorena, B., Marsham, J., Milton, S., Myhre, G., Osborne, S. R., Parker, D. J., Rajot, J.-L., Schulz, M., Slingo, A., Tanré, D., and Tulet, P.: Overview of the Dust and Biomass-burning
Experiment and African Monsoon Multidisciplinary Analysis Special Observing Period-0, J. Geophys. Res., 113, D00C17, doi:10.1029/2008JD010077, 2008.

Heintzenberg, J.: The SAMUM-1 experiment over Southern Morocco: overview and introduction, Tellus, 61B, 2-11, 2009.

Horvath, H.: Influence of atmospheric aerosols upon the global radiation balance, edited by Harrison, R. M. and Van Grieken, R., Atmospheric particles, New York, John Wiley, 543-596, 1998.

Hudson J. G. and Da, X.: Volatility and size of cloud condensation nuclei, J. Geophys. Res., 101, 4435-4442, 1996.

Intergovernmental Panel on Climate Change, Climate Change 2007: The Physical Science Basis, in: Contribution of Working Group I to the Fourth Assessment Report of the Intergovernmental Panel on Climate Change, edited by: Solomon, S., Qin, D., Manning, M., Chen, Z., Marquis, M., Averyt, K. B., Tignor, M., and Miller, H. L., Cambridge Univ. Press, Cambridge, UK, 2007.

Janicot, S., Thorncroft, C. D., Ali, A., Asencio, N., Berry, G., Bock, O., Bourles, B., Caniaux, G., Chauvin, F., Deme, A., Kergoat, L., Lafore, J.-P., Lavaysse, C., Lebel, T., Marticorena, B., Mounier, F., Nedelec, P., Redelsperger, J.-L., Ravegnani, F., Reeves, C. E., Roca, R., de Rosnay, P., Schlager, H., Sultan, B., Tomasini, M., Ulanovsky, A., and ACMAD forecasters team: Large-scale overview of the summer monsoon over West Africa during the AMMA field experiment in 2006, Ann. Geophys., 26, 25692595, doi:10.5194/angeo-26-2569-2008, 2008.

Kalapureddy, M. C. R., Lothon, M., Campistron, B., Lohou, F., Saïd, F.: Wind profiler analysis of the African Easterly Jet in relation with the boundary layer and the Saharan heat-low, Q. J. Roy. Meteorol. Soc., Wiley InterScience, (www.interscience. wiley.com), doi: 10.1002/qj.494, 2009.

Kelly, J. T., Chuang, C. C., and Wexler, A. S.: Influence of dust composition on cloud droplet formation, Atmos. Environ., 41, 2904-2916, 2007.

Kotchenruther, R. and Hobbs, P. V.: Humidification factors of aerosols from biomass burning in Brazil, J. Geophys. Res., 103, 32081-32090, 1998.

Kreidenweis, S. M., McInnes, L. M., and Brechtel, F. J.: Observations of Aerosol Volatility and Elemental Composition at Macquarie Island during the First Aerosol Characterization Experiment (ACE 1), J. Geophys. Res., 103, 16511-16524, 1998.

Lebel, T., Parker, D. J., Flamant, C., Bourlès, B., Marticorena, B., Mougin, E., Peugeot, C., Diedhiou, A., Haywood, J. M., Ngamini, J. B., Polcher, J., Redelsperger, J.-L., and Thorncroft, C. D.: The AMMA field campaigns: multiscale and multidisciplinary observations in the West African region, Q. J. Roy. Meteorol. Soc., Wiley InterScience, (www.interscience.wiley.com), doi:10.1002/qj.486, 2009.

Levin, Z., Ganor, E., and Gladstein, V.: The effects of desert particles coated with sulfate on rain formation in the Eastern Mediterranean, J. Appl. Meteorol., 35, 1511-1523, 1996.

Li, J., Pósfai, M., Hobbs, P. V., and Buseck, P. R.: Individual aerosol particles from biomass burning in southern Africa: 2 . Compsotions and aging of inorganic particles, J. Geophys. Res., 108(D13), 8484, doi:10.1029/2002JD002319, 2003.

Maßling, A., Wiedensohler, A., Busch, B., Neusüß, C., Quinn, P., Bates, T., and Covert, D.: Hygroscopic properties of different aerosol types over the Atlantic and Indian Oceans, Atmos. Chem. Phys., 3, 1377-1397, doi:10.5194/acp-3-1377-2003, 2003.

Matsuki, A., Iwasaka, Y., Shi, G. Y., Chen, H. B., Osada, K., Zhang, 
D., Kido, M., Inomata, Y., Kim, Y. S., Trochkine, D., Nishita, C., Yamada, M., Nagatani, T., Nagatani, M., and Nakata, H.: Heterogeneous sulfate formation on dust surface and its dependence on mineralogy: Balloon-borne measurements in the surface atmosphere of Beijing, China, Water, Air, and Soil Pollution: Focus, 5, 101-132, 2005a.

Matsuki, A., Iwasaka, Y., Shi, G. Y., Zhang, D. Z., Trochkine, D., Yamada, M., Kim, Y. S., Chen, B., Nagatani, T., Miyazawa, T., Nagatani, M., and Nakata, H.: Morphological and chemical modification of mineral dust: Observational insight into the heterogeneous uptake of acidic gases, Geophys. Res. Lett., 32(22), L22806, doi:10.1029/2005GL024176, 2005b.

Matsuki, A., Schwarzenboeck, A., Venzac, H., Laj, P., Crumeyrolle, S., and Gomes, L.: Cloud processing of mineral dust: direct comparison of cloud residual and clear sky particles during AMMA aircraft campaign in summer 2006, Atmos. Chem. Phys., 10, 1057-1069, doi:10.5194/acp-10-1057-2010, 2010.

McConnell, C. L., Highwood, E. J., Coe, H., Formenti, P., Anderson, B., Osborne, S., Nava, S., Desboeufs, K., Chen, G., and Harrison, M. A. J.: Seasonal variations of the physical and optical characteristics of Saharan dust: Results from the Dust Outflow and Deposition to the Ocean (DODO) experiment, J. Geophys. Res., 113, D14S05, doi:10.1029/2007JD009606, 2008.

Mouri, H., Nagao, I., Okada, K., Koga, S., and Tanaka, H.: Elemental composition of individual aerosol particles collected from the coastal marine boundary layer, J. Meteor. Soc. Jap., 74, 585-591, 1996.

O'Dowd, C. D. and Smith M. H.: Physico-chemical properties of aerosol over the North East Atlantic: Evidence for wind speed related sub-micron sea-salt aerosol production, J. Geophys. Res., 98, D1, 1137-1149, 1993.

Ogren, J. A., Heintzenberg J., and Charlson R. J.: In-situ sampling of clouds with a droplet to aerosol converter. Geophys. Res. Lett., 12, 121-124, 1985.

Pinnick, R. G., Jennings, S. G., and Fernandez, G.: Volatility of aerosol in the arid southwestern United States, J. Atmos. Sci., 44, 562-576, 1987.

Pósfai, M., Simonics, R., Li, J., Hobbs, P. V., and Buseck, P. R.: Individual aerosol particles from biomass burning in southern Africa: 1. Compositions and size distributions of carbonaceous particles, J. Geophys. Res., 108(D13), 8483, doi:10.1029/2002JD002291, 2003.

Raut, J.-C. and Chazette, P.: Radiative budget in the presence of multi-layered aerosol structures in the framework of AMMA SOP-0, Atmos. Chem. Phys., 8, 6839-6864, doi:10.5194/acp-86839-2008, 2008.

Redelsperger, J. L., Thorncroft, C. D., Diedhiou, A., Lebel, T., Parker, D. J., and Polcher, J.: African Monsoon Multidisciplinary Analysis: An international research project and field campaign, B. Am. Meteorol. Soc., 87, 1739-1746, doi:10.1175/BAMS-8712-1739, 2006.

Reid, J. S., Koppmann, R., Eck, T. F., and Eleuterio, D. P.: A review of biomass burning emissions part II: intensive physical properties of biomass burning particles, Atmos. Chem. Phys., 5, 799825, doi:10.5194/acp-5-799-2005, 2005.

Rissler, J., Vestin, A., Swietlicki, E., Fisch, G., Zhou, J., Artaxo, P., and Andreae, M. O.: Size distribution and hygroscopic properties of aerosol particles from dry-season biomass burning in Amazonia, Atmos. Chem. Phys., 6, 471-491, doi:10.5194/acp-
6-471-2006, 2006.

Rood, M. J., Larson, T. V., Covert, D. S., and Ahlquist, N. C.: Measurement of laboratory and ambient aerosols with temperature and humidity controlled nephlometry, Atmos. Environ., 19, 1181-1190, 1985.

Rood, M. J., Larson, T. V., and Covert, D. S.: Temperature and humidity controlled nephelometry: improvements and calibration, Aerosol Sci., Technol., 7, 57-65, 1987.

Saïd, F., Canut, G., Durand, P., Lohou, F., and Lothon, M.: Seasonal evolution of boundary-layer turbulence measured by aircraft during the AMMA 2006 Special Observation Period, Q. J. Roy. Meteorol. Soc., Wiley InterScience, (www.interscience.wiley.com), doi:10.1002/qj.475, 2009.

Schwarzenboeck, A. and Heintzenberg, J.: Cut size minimization and cloud element break-up in a ground-based CVI, J. Aerosol Sci., 31, 477-489, 2000.

Schwarzenboeck, A. and Heintzenberg, J., and Mertes, M.: Incorporation of aerosol particles between 25 and $850 \mathrm{~nm}$ into cloud elements: measurements with a new complementary sampling system, Atmos. Res., 52, 241-260, 2000.

Smith, M. H. and O'Dowd, C. D.: Observation of accumulation mode aerosol composition and soot carbon concentrations by means of a high-temperature volatility technique, J. Geophys Res., 101(D14), 19583-19591, doi:10.1029/95JD01750, 1996.

Swap, R. J., Annegarn, H. J., Suttles, J. T., King, M. D., Platnick, S., Privette, J. L., and Scholes, R. J.: Africa burning: A thematic analysis of the Southern African Regional Science Initiative (SAFARI 2000), J. Geophys. Res., 108(D13), 8465, doi:10.1029/2003JD003747, 2003.

Tanré, D., Haywood, J. M., Pelon, J., Léon, J. F., Chatenet, B., Formenti, P., Francis, P., Goloub, P., Highwood, E. J., and Myhre, G.: Measurement and modeling of the Saharan dust radiative impact: Overview of the SaHAran Dust Experiment (SHADE), J. Geophys. Res., 108(D13), 8574, doi:10.1029/2002JD003273, 2003.

Twohy, C. H., Kreidenweis, S. M., Eidhammer, T., Browell, E. V., Heymsfield, A. J., Bansemer, A. R., Anderson, B. E., Chen, G., Ismail, S., DeMott, P. J., and Van Den Heever, S. C.: Saharan dust particles nucleate droplets in eastern Atlantic clouds, Geophys. Res. Lett., 36, L01807, doi:10.1029/2008GL035846, 2009.

Villani, P., Picard, D., Marchand, N., and Laj, P., Design and Validation of a 6-Volatility Tandem Differential Mobility Analyzer (VTDMA), Aerosol Sci. Tech., 41, 10, 898-906, 2007.

Winker, D. M., Hunt, W. H., and McGill, M. J.: Initial performance assessment of CALIOP, Geophys. Res. Lett., 34, L19803, doi:10.1029/2007GL030135, 2007.

Weinbruch, S., Van Aken, P., Ebert, M., Thomassen, Y., Skogstad, A., Chashchin, V. P., Nikonov, A., The heterogeneous composition of working place aerosols in a nickel refinery: a transimission and scanning electron microscope study, J. Environ. Monit., 4, 344-350, 2002.

Woodward, S.: Modeling the atmospheric life-cycle and radiative impact of mineral dust in the Hadley Centre climate model, J. Geophys. Res., 106(D16), 18155-18166, doi:10.1029/2000JD900795, 2001.

Zeng, J., Tohjima, Y., Fujinuma, Y., Mukai, H., and Katsumoto, M.: A study of trajectory quality using methane measurements from Hateruma Island, Atmos. Environ., 37, 1911-1919, 2003. 